\begin{tabular}{|l|c|c|}
\hline Q1. & \multicolumn{3}{|c|}{$\begin{array}{c}\text { Eurasian Academy of Sciences } \\
\text { Eurasian Art \& Humanities Journal } \\
\text { Volume:1 }\end{array}$} & S: $61-80$ \\
\hline
\end{tabular}

\title{
ANALYSIS OF HENNA FOLK SONGS WHICH ARE SITUATED TURKISH RADIO AND TELEVISION CORPORATION TURKISH FOLK SONGS REPERTORY IN TERMS OF THEIR RITM
}

Yakup AÇAR*, Yavuz ŞEN **

Kafkas Üniversitesi*, Atatürk Üniversitesi**

E-mail: yakupacar8@hotmail.com*,yavuzsen@atauni.edu.tr**

Copyright (C) 2015 Yakup AÇAR, Yavuz ŞEN. This is an open access article distributed under the Eurasian Academy of Sciences License, which permits unrestricted use, distribution, and reproduction in any medium, provided the original work is properly cited.

\begin{abstract}
It was aimed to point out the characteristics of rhythm scales for henna folk songs which are situated in TRT Turkish folk songs repertoire. In the framework of this main purpose, it was identified their general characteristics by analyzing folk songs in henna night in terms of their rhythm scales. During this research, documentary survey method was used. Repertoir of TRT Turkish Folk Music constitutes the population of research. The sample group is 75 henna folk songs in repertory of TRT Turkish Folk Music. It was determined that 75 henna night songs in the repertoire of Turkish folk music consisted of 44 joint rhythm scales in the proportion of 58. 6 percent, 13 folk songs with basic rhythm scale in the proportion of 17.4 percent, 10 folk songs with mixed rhythm scale in the proportion of 13.3 percent, 8 folk songs with multi rhythm scale in the proportion of 10.7 percent. This study explored joint rhythm scales were most prevailed among henna night folk songs and as for multi rhythm scale, this proportion was at least. It found out that Henna night folk songs in Turkish folk music repertoir of Radio and Television Council (TRT) comprised of 30 folk songs with $9 / 8$ rhythm scale in the proportion of 40 percent as well as $6 / 8,8 / 8,9 / 4,12 / 8,13 / 8,15 / 8$ rhythm scales in the proportion of 1.3 percent. In addition, 8 henna night folk songs were multi rhythm scale in proportion of 1.3 percent.
\end{abstract}

Keywords: Tradition, Turkish Folk Music, Traditional Turkish Folk Music, Henna, Henna Folk Songs.

\section{TRT Türk Halk Müziği Repertuarında Bulunan Kına Türkülerinin Usûl Yönünden Analizi ${ }^{1}$}

ÖZET: $\mathrm{Bu}$ araştırmada TRT repertuarında bulunan kına türkülerinin usûl özelliklerinin ortaya konulması amaçlanmıştır. Bu temel amaç çerçevesinde kına türküleri usûl yönünden

\footnotetext{
1 *Bu makale, Yakup AÇAR tarafından hazırlanan, Yrd. Doç. Dr. Yavuz ŞEN'in danışmanlığında yürütülmüş “TRT Türk Halk Müziği Repertuarında Bulunan Kına Türkülerinin, Makam Dizileri, Usûl ve Güfte Yönünden Analizi” isimli Yüksek Lisans Tezinin bir bölümünden geliştirilerek oluşturulmuştur.
} 
incelenerek genel özellikleri tespit edilmiştir. Araştırmanın yürütülmesinde belgesel tarama modeli kullanılmıştır. Araştırmanın evrenini, TRT THM repertuarı oluşturmaktadır. Araştırmanın örneklemini ise, repertuarda yer alan 75 kına türküsü oluşturmaktadır. TRT THM Repertuar içerisinde bulunan toplam 75 kına türküsünün \% 58.6 oranıyla 44 türkünün birleşik usûl, \% 17.4 oranıyla 13 türkünün ana usûl, \% 13.3 oranılla 10 türkünün karma usûl, \% 10.7 oranıyla 8 türkünün çoklu usûl olduğu tespit edilmiştir. Kına türkülerinin en çok birleşik usûlde olduğu, en az ise çoklu usûlde olduğu tespit edilmiştir. TRT THM repertuarındaki kına türkülerinin, \% 40 oran ile (30 türkü) 9/8'lik usûldien oluştuğu, \% 1.3 oranla ise $6 / 8,8 / 8,9 / 4,12 / 8,13 / 8,15 / 8$ 'lik usûl olduğu tespit edilmiştir. Ayrıca 8 kına türküsünün de \% 1.3 oranla çoklu usûlde olduğu tespit edilmiştir.

Anahtar Kelimeler: Gelenek, Türk Halk Müziği, Geleneksel Türk Halk Müziği, Kına, Kına Türküleri.

\section{Giriş}

Müzik, ortaya çıktığı kültürden izler taşıyan, kültüre dayalı, kültürü yeni nesillere aktarabilen bir yapıdadır. Türk halk müziği Türk kültürünün yeni nesillere aktarımında bir taşıyıcı role sahiptir. Öncelikle kültür kavramını ele almak gerekirse; "Tarihi süreç içinde insanların meydana getirdiği maddi ve manevi değerlerin bütününe kültür denilmektedir" (Aksoy, 2000: 55). Kültür, bir toplumun manevi özelliğini, duyuş ve düşünüş birliğini kuran, gelenek halinde her türlü yaşayış düşünce ve sanat varlıklarının tümüdür (Turan, 2002: 189). Bu tanımda "gelenek halinde oluşluk" kültürün niteliğini açıklayan bir unsur olarak karşımıza çıkmaktadır. Aynı zamanda kültürün bazı manevi öğelerinin, gelenek aracılığıyla aktarıldığı çağrışımını yapmaktadır. Bu durum da, gelenek kavramının açıklanmasını gerekli kılmaktadır (Aydıner ve diğerleri, 2011: 141).

Ertürk’e göre (1978) “Gelenek” kültürün kuşaktan kuşağa geçerek zamanımıza kadar ulaşmış belli öğelerinde varlığını sürdürür. Bu bakımdan gelenek, "değerini ve gücünü hem eskilikten, hem de öteden beri çeşitli durumlarda denendikten sonra geçerli kalmışlıktan alır". Burada "eskilik, geçerli kalmışlık ve süreğenlik" birlikte düşünüldügünde "eskimezlik" anlamına gelir. Bu demektir ki, gelenek, "kültürdeki eskimezlerden oluşur". Gelenek, "geçmişten gelmekle birlikte, geçmişte kapanıp kalmaz", günümüze erişir, geleceğe uzanır ve böylece "kökü geçmişte olan bir gelecek" gibi anlaşılmak istenir (Akt. Uçan, 2005: 309).

Kuşaktan kuşağa aktarılıp zamanımıza kadar ulaşan kültürel öğelerin başında müzik gelir. "Müzik, ait olduğu kültürün anlaşılmasında önemli bir katkı sağlayabilir. Aynı zamanda, en basit ve en dayanıklı kültürel öğelerden biri olduğu için, söz konusu olan herhangi bir ulus, etnik ya da kültürel bir grubu anlamayı sağlayacak anahtardır" (Clarke, 2001: 38). Bir toplumun anlaşılmasında anahtar olabilecek, bir toplumun müziğinin özel niteliğini, özgünlüğünü oluşturan müzikler, o toplumun geleneksel müzikleridir. Geleneksel müzikler, Türk müzik kültüründe de önemli bir yere sahiptir.

Türk halk müziği de, halkın ortak duygu ve düşüncelerini yansıtan, halk içinde her zaman var olan halk sanatçıları tarafından yakılmış, bestelenmiş, değişimler ve yoğrulmalarla dilden dile, telden tele, kulaktan kulağa yayılarak geçmişten günümüze ulaşmış geleneksel müziktir (Büyükyıldız, 2009: 89). 
Dünyanın başka bir coğrafyasından İngiliz, Breniers'e göre halk müziği; halkın müşterek malı olan, en sade, düz ve yalın ezgiler olduğu ve bestecisinin belli olmadığını söylemiştir (Emnalar, 1998: 25).

Türk kültüründe önemli bir yere sahip olan kına geleneği, ülkemizin pek çok yöresinde uzun yıllardır varlığını devam ettirmektedir. Ülkemizin hemen her yerinde gelinler için, kına gecesi düzenlenir. Düzenlenen bu törenlerde gelinler, söylenen kına türküleri ile ağlatılır. Genellikle kına yakımı esnasında söylenen bu türkülere, yörelere göre çeşitli adlar verilir. Bunlardan bazıları; kına ağıdı, kına havası, kına okşaması, kına ilahisi, kına başı övme türküsü, kadın kına havası, gelin ağlatma türküsü, gelin ağlatma havası, kına türküsü gibi isimlerle adlandirılır (Y1lmaz, 2010: 79-80).

Türküler, belirli bir çerçeve ve yöntem içerisinde bir eser ortaya koymak amacıyla üretilmez. Halkın duygu dünyasını etkileyen herhangi bir etken sonucu, genellikle doğaçlama olarak, kendiliğinden yaratılır, ya da halk ağzıyla "türkü yakılır". Çeşitli etkilerle türkü yaratılması olayına halk arasında "türkü yakmak" denir. (Büyükyıldız, 2009: 129). Türküler, ezgisel yapılarına ve konularına göre birçok şekilde sınıflandırılmaktadır. Kına türküleri ise konu bakımından tören türküleridir, fakat içerik olarak ayrılığı, üzüntüyü kederi temsil ettiği için geleneksel Türk halk müziği araştırmacılarına göre ağıt sınıfında yer almaktadır.

Kına türküleri çeşitli açılardan bölgesel bir değerlendirmeye tabi tutulduğunda bölgeler arasında benzerlik ve farklılıklar ortaya çıktığı görülmektedir. Bu benzerlikler halkımızın ortak kültür unsurlarını oluştururken, farklılıklar ise, bölgelerimizin özgün yapıları ve kültürel zenginliklerini ortaya koymaktadır (Y1lmaz, 2010: 1).

Konumuz itibariyle usulûn tanımı ve Türk halk müziğindeki usûllerin çeşitleri aşağıda verilmiştir.

\section{Usûl}

Usûl, belirli düzümlerden oluşan, kalıp halinde tespit edilmiş ölçülerdir. Bir başka ifadeyle, düzümün özel kalıplar haline getirilmiş şeklidir. Vuruşların değerleri birbirine eşit veya eşit olmayabilmektedir. Ancak kuvvetli, yarı kuvvetli ve zayıf zamanların değişik şekilde sıralanma, usûller arasındaki farklılaşmayı meydana getirmektedir. Bir usûlün oluşabilmesi için en azından bir kuvvetli, bir zayıf vuruşa ihtiyaç vardır (Emnalar, 1998: 110).

\section{Geleneksel Türk Halk Müziği’nde Usûller}

Türk Halk Musikisi usûllerini kendi bünyesinin icaplarına göre tasnif edilince, bu usûllerin başlıca üç esasa dayandığı görülmektedir (Sarısözen, 1962: 6).

\section{Ana Usûller}

Türk Halk Musikisi usûllerinin temelini oluşturan ana usûller iki, üç ve dört vuruşlarla bunların üçerli şeklidir. Bu usûllerden iki ve dört vuruşlularla bunların üçerli şekilleri çok, üçlülerin üçerli şekilleri azdır (Sarısözen, 1962: 8).

İki vuruşlular $(2 / 2,2 / 4,2 / 8)$, üçerli şekli $(2+2+2=6 / 8)$. Üç vuruşlular $(3 / 4,3 / 8)$, üçerli şekli $(3+3+3=9 / 8)$. Dört vuruşlular $(4 / 4)$, üçerli şekli $(4+4+4=12 / 8)$ şekilleri halinde ifade edilmektedir (Büyükyıldız, 2009: 157). 


\section{Birleşik Usûller}

Sarısözen (1962) birleşik usûllere ilişkin olarak şu görüşleri belirtmektedir;

"Ana usûllerin belli kurallar gereğince bir araya gelmesiyle oluşmaktadır. Birleşik usûller, halk müziğinin en önemli ve en zengin tarafidır. Aslında ana usûllerin birleşmesinden başka bir şey olmayan bu usûllerde ikili ve üçlülerin sıralanışındaki incelik bütün dünya müzik âlemini ilgilendirecek kadar renkli ritm özellikleri oluşturur" (s. 54).

Beş vuruşlular $(5 / 4,5 / 8)$ şeklinde olup $A(3+2)$ ve $B(2+3)$. Altı vuruşlular $(6 / 4,6 / 8)$ olup $(4+2)$ ve $(3+3)$. Yedi vuruşlular $(7 / 4,7 / 8)$; A $(3+2+2)$, B $(2+3+2)$, C $(2+2+3)$. Sekiz vuruşlular (8/8); A $(2+3+3)$, B (3+2+3), C (3+3+2). Dokuz vuruşlular $(9 / 4,9 / 8,9 / 16)$; A $(3+2+2+2), \mathrm{B}(2+3+2+2), \mathrm{C}(2+2+3+2), \mathrm{D}(2+2+2+3)$ şekilleri halindedir (Büyükyıldız, 2009: 157).

\section{Karma Usûller}

Sarısözen (1962) tarafından karma usûllerin değerlendirilmesi şöyledir; "Karma usûller adı altında topladığımız bu grup, birleşik usûllerin veya ana usûllerle birleşik usûllerin bir araya gelmesiyle oluşur. Ana ve birleşik usûllere göre daha az bulunan karma usûller, ritm yönünden ilginç özellikler gösterir. Karma usûllerin birçok rastlanmaktaysa da biz bunlardan muntazam olan ve yapılışından bir kural çıkarılabilenleri ele almış bulunuyoruz. Bugüne kadar yapılışı bir kuralla açıklanabilen sekiz türlü karma usûl tespit edilmiştir. Bunlar; 10, 11, 12, 15, 16, 18, 20, 21 zamanlı karma usûllerdir. Yarın, belki başka çeşittlerini de bulacağız fakat bundan sonra karşılaşmamız ihtimali olan yeni bir karma usûlün, burada açıkladığımız kuralların dişında kalmayacağı kuvvetle tahmin edilebilir” (s. 96).

On vuruşlular $(10 / 4,10 / 8,10 / 16)$; $\mathrm{A}[\mathrm{a}(3+2)+\mathrm{b}(2+3)], \mathrm{B}[\mathrm{b}(2+3)+\mathrm{a}(3+2)]$ şeklinde, on bir vuruşlular A $(7+4), \mathrm{B}(5+6)$ şeklinde, on iki vuruşlular A $(2+3+2+3+2), \mathrm{B}(3+2+2+2+3)$ şeklinde, on beş vuruşlular $(15 / 4,15 / 8)$; A $(7+8)$ iki birleşik usûl, B (7+8) bir birleşik, iki ana usûl, C (8+7) iki birleşik usûl şeklindedir (Büyükyıldız, 2009: 159).

On altı vuruşlular $(16 / 8),(9+7)$ şeklinde, on sekiz vuruşlular $(18 / 8),(12 / 8+6+8)$ şeklinde, yirmi vuruşlular $(20 / 8)$; [(3+3) $(6 / 8)+(2+2+3)(7 / 8)+(3+2+2)(7 / 8)]$ şeklinde, yirmi bir vuruşlular (21/8); (12/8+9/8) şeklindedir (Büyükyıldız, 2009: 159).

\section{Araştırmanın Amacı}

$\mathrm{Bu}$ araştırmada TRT repertuarında bulunan kına türkülerinin usûl özelliklerinin ortaya konulması amaçlanmıştır. $\mathrm{Bu}$ temel amaç çerçevesinde kına türküleri usûl yönünden incelenerek genel özellikleri tespit edilecektir.

\section{Yöntem}

Bu araştırmanın yürütülmesinde belgesel (yapılanmış) tarama modeli kullanılmıştır.

Genel tarama modelleri, çok sayıda elemandan oluşan bir evrende, evren hakkında genel bir yargıya varmak amacı ile evrenin tümü ya da ondan alınacak bir grup, örnek ya da örneklem üzerinde yapılan tarama düzenlemeleridir. Araştırmaya konu olan olay, birey ya da nesne, kendi koşulları içinde ve olduğu gibi tanımlanmaya çalışılır (Karasar, 2008: 79). 
Var olan kayit ve belgeleri inceleyerek veri toplamaya belgesel tarama denir. Tarananlar; geçmişteki olguların anında iz bıraktığı resim, film, plak, ses ve resim kayıtları bantlar, araç gereç, bina heykel, vb. kalıntılarla; olgular hakkında, sonradan yazılmış ve çizilmiş her türlü mektup, rapor, kitap, ansiklopedi, resmi ve özel yazı ve istatistikler, tutanak, anı yaşam öyküsü ve benzerleridir (Akbaş, 2005: 1).

TRT THM sözlü eserler repertuarında bulunan kına türküleri belgesel tarama tekniği ile tespit edilmiştir.

\section{Evren Örneklem}

Araştırmanın evreni, Türkiye Radyo Televizyon Kurumunun, Türk Halk Müziği repertuarında bulunan (4667) kırık havadan oluşmaktadır. Örneklemi ise, TRT THM repertuarında bulunan 75 kına türküsüdür.

Araştırmada TRT THM repertuarında bulunan kına türküleri taranarak tespit edilmiştir. Bu veriler ışığında TRT THM repertuarında bulunan türküler; repertuar numaralarına göre, Tablo 1'de gösterilmiştir. İlgili tabloda her bir esere ait; Repertuar Numaraları, Eser adları, İli, Kaynak Kişi ve Derleyen bilgileri sunulmuştur.

Tablo 1. TRT THM Repertuarında Bulunan Kına Türküleri

\begin{tabular}{|c|c|c|c|c|}
\hline $\begin{array}{l}\text { Rep. } \\
\text { No }\end{array}$ & Eser Adı & İli & Kaynak Kişi & Derleyen \\
\hline 7 & $\begin{array}{l}\text { A } \breve{g} \text { Elime Mor Kınalar } \\
\text { Yakdılar }\end{array}$ & Denizli/Acıpayam & Süleyman Uğur & Nida Tüfekçi \\
\hline 15 & $\begin{array}{l}\text { Düngürcüler Geldi Sira } \\
\text { Sira Dizildi }\end{array}$ & Erzurum & Muharrem Akkuş & $\begin{array}{l}\text { Muharrem } \\
\text { Akkuş }\end{array}$ \\
\hline 100 & Varın Sorun Babasına & Tekirdağ/Şarköy & Mustafa Karayer & Yücel Paşmakçı \\
\hline 156 & Gıcılar Kavak Gicılar & $\begin{array}{l}\text { Hac1 } \quad \text { Bektaş/lilicek } \\
\text { Köyü }\end{array}$ & Mürset Karadăg & Mine Yalçın \\
\hline 157 & Atladı Çıkdı Eşiği & Hacı Bektaş & Selvet Aslan & Ali Galip Yalçın \\
\hline 190 & $\begin{array}{l}\text { Yüksek Tepelere } \\
\text { Kurmasinlar }\end{array}$ & Edirne/Yolüstü Köyü & Kızlar Ekibi & Ümit Kaftanc1 \\
\hline 255 & Kıcılar Kavak Kıcılar & Akşehir & Şakir Güleroğlu & $\begin{array}{l}\text { Muzaffer } \\
\text { Sarısözen }\end{array}$ \\
\hline 300 & Atlar Eğerlendi & Arapkir & Sadettin Özdağ & $\begin{array}{l}\text { Muzaffer } \\
\text { Sarısözen }\end{array}$ \\
\hline 319 & Atladı Geçti Eşiği & Sivas & Yaşar Moral & $\begin{array}{l}\text { Muzaffer } \\
\text { Sarısözen }\end{array}$ \\
\hline 354 & $\begin{array}{l}\text { Anam Yoğurdunu Ayran } \\
\text { Eylesin }\end{array}$ & Çemişkezek & Vasfi Akyol & $\begin{array}{l}\text { Muzaffer } \\
\text { Sarısözen }\end{array}$ \\
\hline 356 & $\begin{array}{l}\text { Anam Beni Haslarınan } \\
\text { Hasladı }\end{array}$ & Elbistan/Elmalıköy & Ali Rıza Yüksel & $\begin{array}{l}\text { Muzaffer } \\
\text { Sarısözen }\end{array}$ \\
\hline 617 & Haydi Gedah Toyuna & Diyarbakır & Cemil Değer & $\begin{array}{l}\text { Muzaffer } \\
\text { Sarısözen }\end{array}$ \\
\hline 624 & Ayletmen Gelini Yazık & Isparta & $\begin{array}{l}\text { Dudu Şengül } \\
\text { Fatma Günyıl }\end{array}$ & $\begin{array}{l}\text { Muzaffer } \\
\text { Sarısözen }\end{array}$ \\
\hline 669 & $\begin{array}{ll}\text { Yüksek Ayvanlarda } \\
\text { Bülbüller Öter }\end{array}$ & Malatya & Hakkı Coşkun & $\begin{array}{l}\text { Muzaffer } \\
\text { Sarısözen }\end{array}$ \\
\hline 709 & Çaktılar Çakmak Taşını & Sivas/Ulaş & Fikriye Doğuyurt & Arif Meşhur \\
\hline 735 & Kızardı Kayalar & Kemaliye & Refik Aktan & $\begin{array}{l}\text { Muzaffer } \\
\text { Sarıözen }\end{array}$ \\
\hline
\end{tabular}




\begin{tabular}{|c|c|c|c|c|}
\hline 810 & Seyirttim Çıktım Hanaya & Denizli & Sıdıka Saraçoğlu & Muzaffer \\
\hline 868 & $\begin{array}{l}\text { Aşağıdan } \quad \text { Gele } \quad \text { Gele } \\
\text { Geldiler }\end{array}$ & Yozgat/Boğazliyan & Sabiha Kubilay & $\begin{array}{l}\text { Sarısözen } \\
\text { İclal Akkaplan }\end{array}$ \\
\hline 899 & Haydin Arkadaşlar & Dinar & Ali Taş & Yücel Paşmakçı \\
\hline 956 & Dağdan Keserler Meşeyi & Eskişehir & Köy Hanımları & $\begin{array}{l}\text { Muammer } \\
\text { Uludemir }\end{array}$ \\
\hline 966 & Şu Tepenin Öte Yüzü & $\begin{array}{l}\text { Seyitgazi/Kırkakümbet } \\
\text { Köyü }\end{array}$ & Köy Hanımları & $\begin{array}{l}\text { Muammer } \\
\text { Uludemir }\end{array}$ \\
\hline 1128 & Zandalya Getirin & Akseki & $\begin{array}{l}\text { Ali Çatli/Mehmet } \\
\text { Pantır }\end{array}$ & $\begin{array}{l}\text { Durmuş } \\
\text { Yazıcığlu }\end{array}$ \\
\hline 1161 & Kınası Karılır Tasta & Afyon/Karahisar & Abdullah Uluçelik & $\begin{array}{l}\text { Muzaffer } \\
\text { Sarı̈özen }\end{array}$ \\
\hline 1233 & Salına Salına & Denizli/Sarayköy & - & $\begin{array}{l}\text { Muzaffer } \\
\text { Sarıöözen }\end{array}$ \\
\hline 1263 & Çatdılar Ocak Taşını & Silifke & Silifke Ekibi & Cavit Erden \\
\hline 1309 & $\begin{array}{l}\text { Altın Tas İçinde Kınam } \\
\text { Ezdiler }\end{array}$ & Kütahya & Hisarlı Ahmet & Yücel Paşmakçı \\
\hline 1397 & Atladı Gitti Eşiği & Bursa & Bedia Yönetken & $\begin{array}{l}\text { Halil Bedî̂ } \\
\text { Yönetken }\end{array}$ \\
\hline 1414 & Atladı Çıktı Eşiği & Beyşehir/Balkana Köyü & İbrahim Çöğür & Ahmet Yamacı \\
\hline 1440 & Atlayıp Gemine & Fethiye/Günlükbaşı & Fatma Hancıoğlu & Hamdi Özbay \\
\hline 1477 & Çatdılar Ocak Daşını & Akdağmadeni/Oluközü & Halime Tunç & Nida Tüfekçi \\
\hline 1639 & Ocağa Koydular & Reşadiye & Mihri Can Bahar & Nida Tüfekçi \\
\hline 1746 & Mübareki & Diyarbakır & Şakire Kalaycı & Bedri Ayseli \\
\hline 1937 & Evlerine Vardım Akşam & Senirkent & Hüseyin Karatürk & $\begin{array}{l}\text { TRT Ankara } \\
\text { Radyosu }\end{array}$ \\
\hline 1988 & Yüzüğüm Var Altaşlı & Denizli/Acıpayam & Mansur Kaymak & Mansur Kaymak \\
\hline 1995 & Oy Gelin Kınan Kutlola & Antakya/İskenderun & Nimet Nerkiz & $\begin{array}{l}\text { Ankara Devlet } \\
\text { Konsv. }\end{array}$ \\
\hline 2154 & Kınayı Ezerler Tasda & Erzurum & - & Remzi Dane \\
\hline 2295 & Getirin Gına Yakalım & Zonguldak/Safranbolu & - & $\begin{array}{l}\text { İstanbul Beld. } \\
\text { Konsv. }\end{array}$ \\
\hline 2320 & $\begin{array}{l}\text { Kuyudan } \mathrm{Su} \quad \text { Çekerler } \\
\text { Tulumunan }\end{array}$ & Erzincan & Hüseyin Engin & Yücel Paşmakçı \\
\hline 2350 & Vurun Gelin Kinasın & Edirne/Uzunköprü & - & $\begin{array}{l}\text { Muzaffer } \\
\text { Sarıözen }\end{array}$ \\
\hline 2470 & Bizim Bağın Kıracı & Elazı ̆̆ & Enver Demirbağ & TRT \\
\hline 2511 & Gurdular Düğün Daşını & $\begin{array}{l}\text { Manisa/Sancaklı Boz } \\
\text { Köy }\end{array}$ & Hasan Avcı & İsmet Egeli \\
\hline 2543 & Bacanızda Ot Muydum & - & Satı Göktaş & Leyla Göktaş \\
\hline 2583 & Hey Bostanc1 Bostanc1 & Denizli/Acıpayam & Mansur Kaymak & Mansur Kaymak \\
\hline 2630 & Havalar Ayaz Gelin Hanım & Adiyaman & Mahmut Çetinkaya & Mehmet Seske \\
\hline 2759 & $\begin{array}{l}\text { Annem Beni Kaldırmışsın } \\
\text { Atmışsın }\end{array}$ & Konya & Nuri Cennet & Mehmet Özbek \\
\hline 2810 & Göster Ey Allahım & Rumeli & Nadire Uysal & $\begin{array}{l}\text { Ankara Devlet } \\
\text { Konsv. }\end{array}$ \\
\hline 2872 & Çattılar Gazan Taşını & Manisa/Salihli & Hayriye Yilmaz & $\begin{array}{l}\text { Ankara Devlet } \\
\text { Konsv. }\end{array}$ \\
\hline 2874 & Çattılar Ocak Taşını & Manisa & Zehra Güler & $\begin{array}{l}\text { Ankara Devlet } \\
\text { Konsv. }\end{array}$ \\
\hline 3224 & $\begin{array}{l}\text { Damda Durma Kahküllerin } \\
\text { Yel Alır }\end{array}$ & $\begin{array}{l}\text { Kemaliye/Yakuplu } \\
\text { köyü }\end{array}$ & Melehat Turgut & Mustafa Özgül \\
\hline 3236 & Damat Beyi Yandıralım & Ankara/Elmadağ & İsmet Sargin & Nida Tüfekçi \\
\hline 3270 & Gelini Getirdiler & Şanlıurfa & Ahmet Bağrıyanık & Ahmet \\
\hline
\end{tabular}




\begin{tabular}{|c|c|c|c|c|}
\hline & & & & Bağrıyanık \\
\hline 3282 & Elma Attım Denize & Rumeli & Sabri Gençler & Nihat Kaya \\
\hline 3371 & Ak Bakırlar & Boyu/Aşağ1 & Osman Şanlituna & Necmi Berbergil \\
\hline 3403 & Bazarda Bal Var & Fethiye & $\begin{array}{l}\text { Fatma } \\
\text { Kaya/Türkan } \\
\text { Demir/Emine } \\
\text { Çakıroğlu }\end{array}$ & $\begin{array}{l}\text { Mustafa } \\
\text { Hoşsu/Talip } \\
\text { Özkan }\end{array}$ \\
\hline 3455 & Baba Aydın'a Vardın Mı & Aydın/Nazilli & Hediye Hüseyin & Ahmet Günday \\
\hline 3460 & Getirin Kına Yakalım & Fethiye & Fatma Kaya & Ahmet Günday \\
\hline 3515 & Ak Bakraçlar Susuz Galdı & Sinop/Çevre Köyleri & Remziye Güven & Ferruh Güven \\
\hline 3552 & Çattılar Gazan Daşını & Uşak/Eşme & Fadime Kılınç & $\begin{array}{l}\text { Celâl } \\
\text { Vural/Gülseren } \\
\text { Aygün }\end{array}$ \\
\hline 3600 & Ana Meni Yaz Ağla & Kars & Mürsel Kılıç & Ali Haydar Gül \\
\hline 3670 & $\begin{array}{l}\text { Altın Tas İçinde Kınam } \\
\text { Karıldı }\end{array}$ & Muğla Fethiye & $\begin{array}{l}\text { Hanım } \\
\text { Çelik/Yaprak } \\
\text { Güven/Ayşe } \\
\text { Hancioğlu/Nurten } \\
\text { Demir }\end{array}$ & Sümer Ezgü \\
\hline 3699 & Baba Gızın Çok Mudur & Adana & Yöre Ekibi & Esat Kabaklı \\
\hline 3725 & $\begin{array}{l}\text { Hani Davulunuz (Bir } \\
\text { Mumdur) }\end{array}$ & Diyarbakır & Gıyas Coşkun & Soner Özbilen \\
\hline 3729 & Çattılar Gazan Daşını & Afyon/Sincanlı & $\begin{array}{l}\text { İbrahim } \quad \text { Hidır } \\
\text { Bozan }\end{array}$ & $\begin{array}{l}\text { TRT Müz. } \\
\text { Dairesi. Bşk. }\end{array}$ \\
\hline 3785 & Atladım Gittim Eşiği & Kayseri/Tomarza & Mehmet Gurnaz & İsmail Sağlam \\
\hline 3936 & $\begin{array}{l}\text { Anam Kirmenini Alsin } \\
\text { Eline }\end{array}$ & $\begin{array}{l}\text { Kırşehir/Mucur/Kırcaali } \\
\text { Köyü }\end{array}$ & $\begin{array}{l}\text { H. Canatan/A. } \\
\text { Duvan/ } \\
\text { A. Gündüz }\end{array}$ & 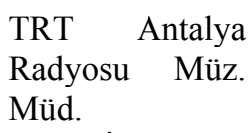 \\
\hline 3967 & $\begin{array}{l}\text { Yüksek Hanaylarda } \\
\text { Çalınsın Sazım }\end{array}$ & Burdur/Kozağacı & Faik İnce & Hamit İnce \\
\hline 3998 & $\begin{array}{ll}\text { Verdiğin } & \text { Yazmay } \\
\text { Bürüneyim Mi } & \end{array}$ & Kayseri & Osman Özdemir & Banttan Alınd 1 \\
\hline 4237 & Ayleme Gelin Ayleme & Bilecik/Kandilli Köyü & Nuriye Y1lmaz & $\begin{array}{l}\text { Saadet Yilmaz } \\
\text { Bircan }\end{array}$ \\
\hline 4244 & Kınaya Gel Kınaya & Erzincan/Kemâliye & Burhan Tarlabaşı & Nida Tüfekçi \\
\hline 4354 & Hani Şu Gızın Anası & Çankırı/Çerkeş & Mehmet Çelen & $\begin{array}{l}\text { Haldun } \\
\text { Karabudak }\end{array}$ \\
\hline 4440 & Devecioğlu Bayırına & Adana/Kozan & Mehmet Ak1l & Semih Esin \\
\hline 4569 & Kınayı Getir Aney & Doğu Anadolu & Yöre Ekibi & İzzet Altınmeşe \\
\hline 4592 & Gız Anası Gız Anası & $\begin{array}{l}\text { Adana/Kadirli/Avluk } \\
\text { Köyü }\end{array}$ & Ahmet Torun & $\begin{array}{l}\text { Ankara Devlet } \\
\text { Konsv. }\end{array}$ \\
\hline 4598 & Adem Havva'yı Yarattı & Amasya & Fatma Samsun & $\begin{array}{l}\text { Ankara Devlet } \\
\text { Konsv. }\end{array}$ \\
\hline 4600 & Geline Bakın Geline & Amasya & Naciye Perin & $\begin{array}{l}\text { Ankara Devlet } \\
\text { Konsv. }\end{array}$ \\
\hline
\end{tabular}

TRT repertuarında toplam 4667 türkü taranmış ve bu repertuar içerisinde 75 adet kına türküsü olduğu görülmüştür. TRT THM repertuarının \%.1,6'sını kına türkülerinin oluşturduğu tespit edilmiştir. 
Tablo 2. Kına Türkülerinin TRT THM Repertuarı İçerisindeki Oran Tablosu

\begin{tabular}{ccc}
\hline & $\mathrm{f}$ & $\%$ \\
\hline Kına Türküleri & 75 & 1.6 \\
Diğgr Türküler & 4592 & 98.4 \\
Toplam & 4667 & 100 \\
\hline
\end{tabular}

\section{Bulgular ve Yorum}

Kına türküleri usûl yönünden analiz edilmiştir. Eserlerin usûl analizi TRT THM sözlü repertuarında bulunan 75 eserin analizi yapılmıştır. Elde edilen bulgular, tablo 3.'te frekans ve yüzde dağılımları aşağıda belirtilmiştir.

Tablo 3. Kına Türkülerinin "Usûl” Oranları Tablosu

\begin{tabular}{|c|c|c|c|c|}
\hline \multicolumn{3}{|c|}{$\overline{\text { USÛL }}$} & \multirow[b]{2}{*}{ f } & \multirow[b]{2}{*}{$\%$} \\
\hline Tür & Zaman & Birim & & \\
\hline \multirow{3}{*}{$\stackrel{\pi}{E}$} & 2 & 4 & 3 & 4.0 \\
\hline & 3 & 4 & 2 & 2.7 \\
\hline & 4 & 4 & 8 & 10.7 \\
\hline \multicolumn{3}{|c|}{ Toplam } & 13 & 17.4 \\
\hline \multirow{8}{*}{ 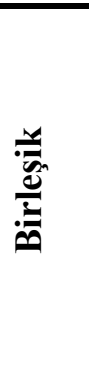 } & 5 & 8 & 4 & 5.3 \\
\hline & 6 & 8 & 1 & 1.3 \\
\hline & 6 & 4 & 2 & 2.7 \\
\hline & 7 & 8 & 2 & 2.7 \\
\hline & 8 & 8 & 1 & 1.3 \\
\hline & 9 & 4 & 1 & 1.3 \\
\hline & 9 & 8 & 30 & 40 \\
\hline & 9 & 16 & 3 & 4.0 \\
\hline \multicolumn{3}{|c|}{ Toplam } & 44 & 58.6 \\
\hline \multirow{4}{*}{ 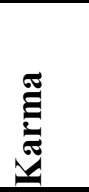 } & 10 & 8 & 7 & 9.4 \\
\hline & 12 & 8 & 1 & 1.3 \\
\hline & 13 & 8 & 1 & 1.3 \\
\hline & 15 & 8 & 1 & 1.3 \\
\hline \multicolumn{3}{|c|}{ Toplam } & 10 & 13.3 \\
\hline \multirow{8}{*}{$\begin{array}{l}\frac{\Xi}{x} \\
\text { en } \\
\end{array}$} & \multicolumn{2}{|c|}{$2 / 4+3 / 4$} & \multirow{8}{*}{8} & \multirow{8}{*}{10.7} \\
\hline & \multicolumn{2}{|c|}{$3 / 4+4 / 4$} & & \\
\hline & \multicolumn{2}{|c|}{$4 / 4+9 / 4$} & & \\
\hline & \multicolumn{2}{|c|}{$9 / 8+10 / 8$} & & \\
\hline & \multicolumn{2}{|c|}{$9 / 8+14 / 8$} & & \\
\hline & \multicolumn{2}{|c|}{$14 / 8+9 / 8$} & & \\
\hline & \multicolumn{2}{|c|}{$12 / 8+10 / 8+8 / 8$} & & \\
\hline & \multicolumn{2}{|c|}{$18 / 8+13 / 8+11 / 8$} & & \\
\hline \multicolumn{3}{|c|}{ Toplam } & 8 & 10,7 \\
\hline \multicolumn{3}{|c|}{ Genel Toplam } & 75 & 100 \\
\hline
\end{tabular}

Tablo 3. incelendiğinde TRT THM Repertuar içerisinde bulunan toplam 75 kına türküsünün $\% 58.6$ oranıyla 44 türkünün birleşik usûl, \% 17.4 oranıyla 13 türkünün ana usûl, $\% 13.3$ oranıyla 10 türkünün karma usûl, \% 10.7 oranıyla 8 türkünün çoklu usûl olduğu tespit edilmiştir. Kına türkülerinin en çok birleşik usûlde olduğu, en az ise çoklu usûlde olduğu tespit edilmiştir. $\mathrm{Bu}$ araştırmada, kına türkülerinin dört farklı usûlde olduğu tespit edilmiş 
olup, bu usûllerin her birine ilişkin usûl analizlerini örneklendirmek amaciyla 4 türküye yer verilmiştir.

TRT MÜZIK DAIRESI YAYINLARI

THM REPERTUAR SIRA NO: 1414

INCELEME TARIHI: 25/05/1977

YÖRESI

BEYŞEHIR-Balkana Köyü

KIMDEN ALINDIĞI

İBRAHIM ÇÖĞÜR

SÜPESI: $d=84$
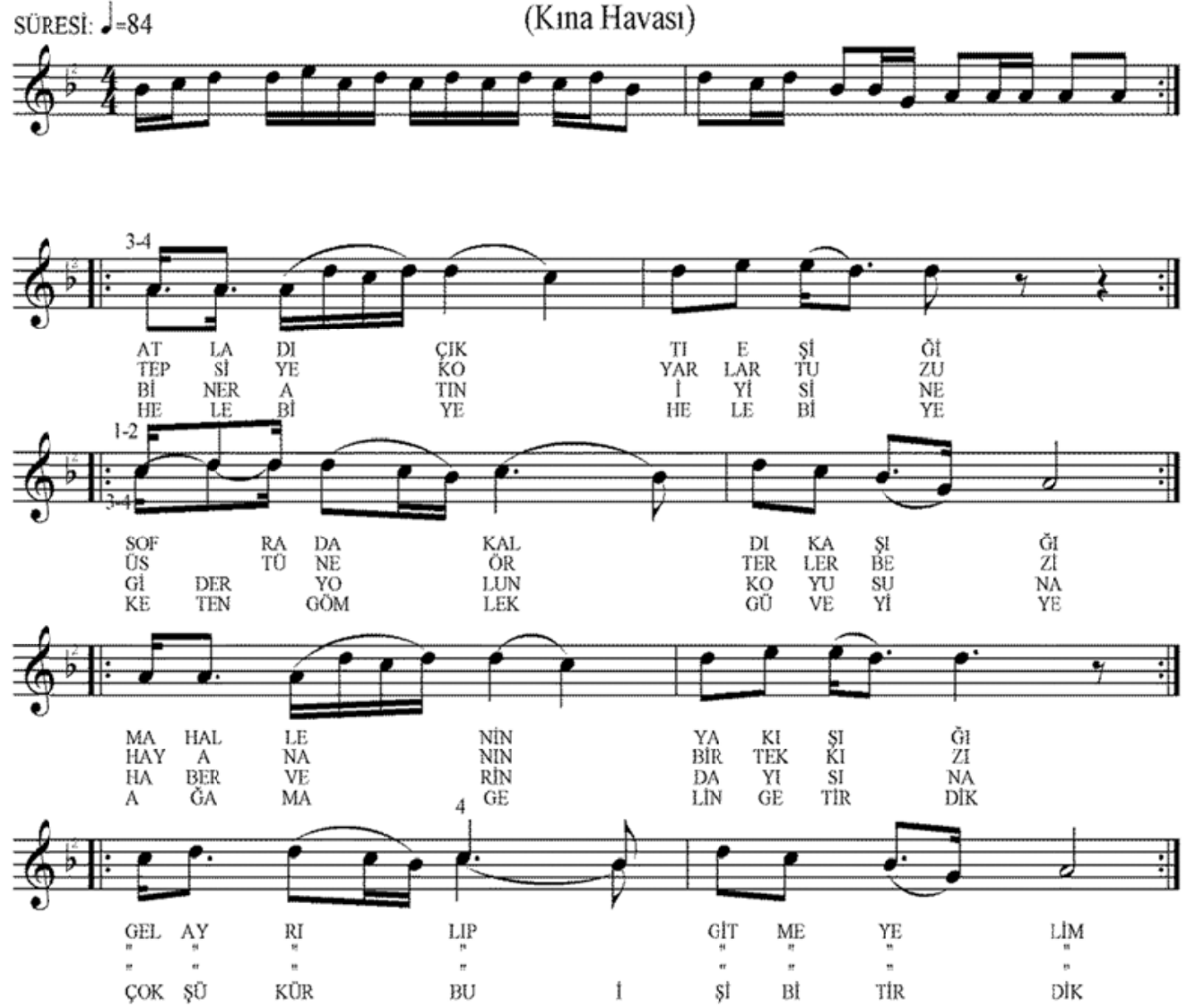

$-1-$

ATLADI CIKTI ESSIĞİ

SOFRADA KALDI KAȘIĞI

MAHALLENIN YAKIŞIĞI

GEL AYRILIP GITMEYELIM

$-2-$

TEPSIYE KOYARLAR TUZU

ÜSTÜNE ÖRTERLER BEZI

HAY ANANIN BİR TEK KIZI

GEL AYRILIP GITMEYELIM
DERLEYEN

AHMET YAMACI

DERLEME TARIHI

NOTAYA ALAN AHMET YAMACI

\section{ATLADI ÇIKTI EŞIĞİ}

(Kina Havası) 


\section{TÜRKÜNÜN KİMLİK BİLGILERİ}

\author{
Adı \\ Repertuar No \\ Yöresi \\ Kimden Alındı̆̆ı \\ Derleyen
}

: Atladı Çıktı Eşiği

: 1414

: Beyşehir-Balkana Köyü

: İbrahim ÇÖĞÜR

: Ahmet YAMACI

\section{TÜRKÜNÜN USÛL ANALİZi}

TRT THM sözlü eserler repertuarında $\mathbf{1 4 1 4}$ no’lu repertuar olan “Atladı Çıktı Eşiğgi” adlı eserin usûl analizi aşağıdaki gibidir.

\section{Zaman}

Geleneksel Türk halk müziği nazariyatına göre; analizi yapılan eserin usûlü, 4 zamanlı usûller kapsamına girmektedir. Bu usûl, Geleneksel Türk sanat müziği usûlleri içerisinde Sofyan olarak adlandırılmaktadır.

\section{Birim}

Eser, 4 zamanlı usûl ve mertebe olarak 4'lük birim ile gösterilmiştir. Atladı Çıktı Eşiği adlı eserin usûlünün, 4/4'lük olduğu görülmektedir.

\section{Usûl Türü}

4/4'lük usûl GTHM nazariyatına göre; Ana usûller olarak gösterilmektedir.

\section{Usûl Kalıpları}

4/4'lük olan eserde kullanılan ritmik kalıplar içerisinde uzatma noktalı kalıplarda kullanılmıştır. Eserde kullanılan ritmik kalıplar aşağıdaki gibidir.

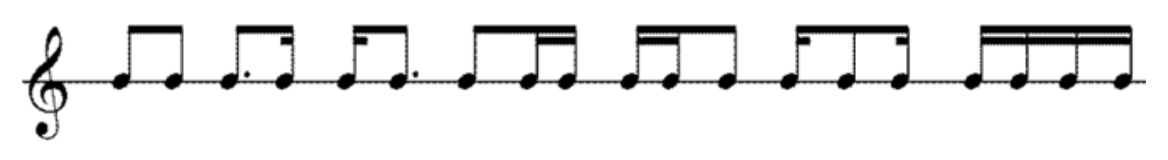

\section{Metronom}

Eserin metronomu repertuar notası üzerinde süre değeri ile gösterilmiştir. Süre değeri olarak

• = 84 gösterilmiştir. Yavaş icra edilmesi gereken bu metronomda birim süre 4'lük cinsinden gösterildiği tespit edilmiştir.

Adagio - Yavaş (76-84 bpm) tempo ile icra edilmesi ve bu bilgiler doğrultusunda eser, adagio: yavaş icra edilmesi gerektiği düşünülmektedir.

\section{Nota Süreleri}

Eser içerisinde, süreleri bakımından en uzun nota 2 vuruş değerindeki ikilik nota, en kısa nota süresi ise $1 / 4$ değerindeki on altılık nota olduğu tespit edilmiştir. Eserde, 1 vuruş değerindeki dörtlük ve $1 / 2$ değerindeki sekizlik notalar da kullanılmıştır. 
TRT MÜZIK DAIRESI YAYINLARI

THM REPERTUAR SIRA NO: 4600

INCELEME TARIHI: 18/11/2005

YÖRESI

AMASYA

KiMDEN ALINDIĞI

NACIYE PERIN

SÜRESI:
DERLEYEN

ANK. DEV. KONS.

DERLEME TARIHI

06/07/1943

NOTAYA ALAN ALTAN DEMIREL
GELINE BAKIN GELINE

(Kina Havasi)

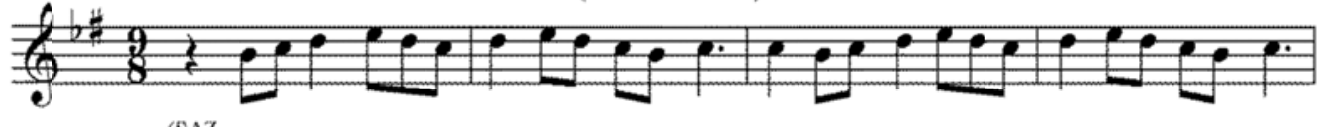

(SAZ
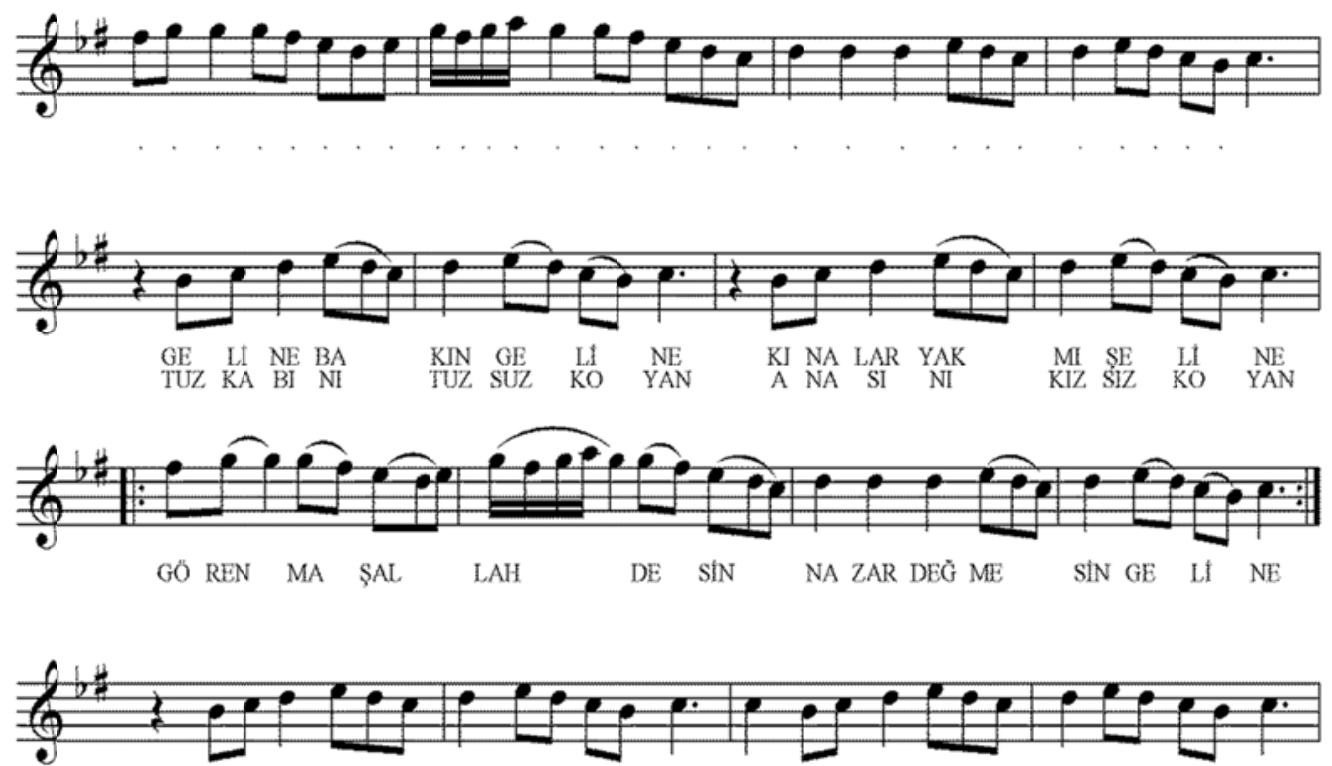

(SAZ
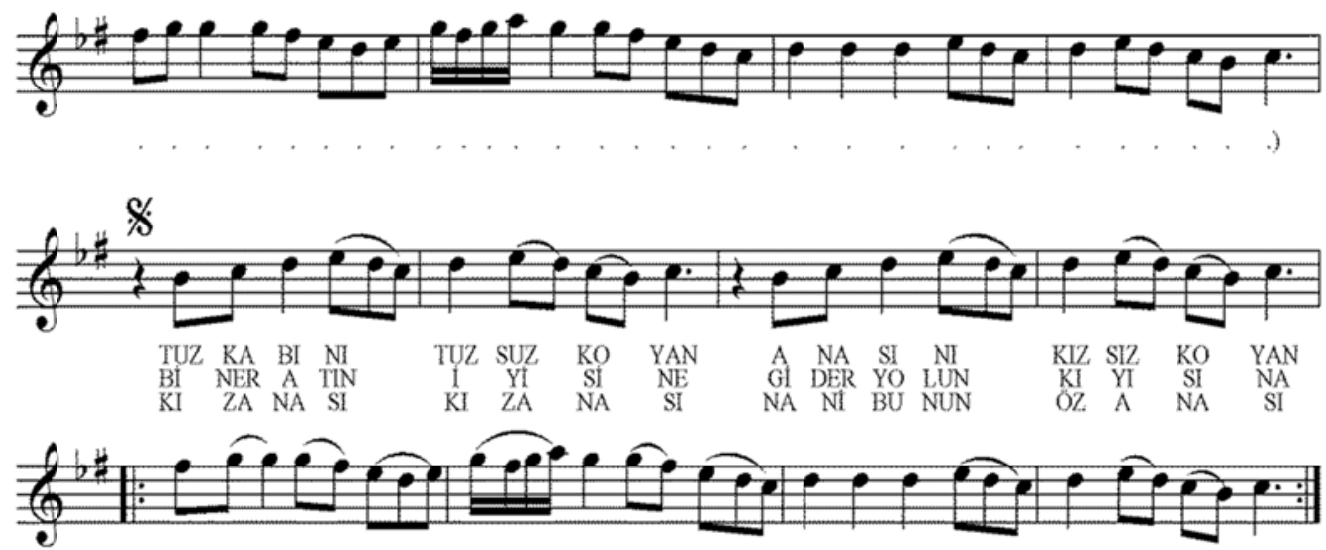

$\begin{array}{llllllllllll}\text { KO } & \text { CA } & \text { E } & \text { VI } & \text { IS } & \text { SIZ KO } & \text { YAN } & \text { KI ZIM KI NAN } & \text { KUT LU } & \text { OL } & \text { SUN } \\ \text { SE } & \text { LA } & \text { ME } & \text { DIN } & \text { DA } & \text { YI SI } & \text { NA } & \text { KI ZIM KI } & \text { NAN } & \text { KUT LU } & \text { OL } & \text { SUN } \\ \text { BAK } & \text { KI } & \text { ZIN } & \text { GE } & \text { LI } & \text { NO LU } & \text { YOR } & \text { GE LAG LA } & \text { KI } & \text { KI ZI } & \text { NA } & \text { SI }\end{array}$




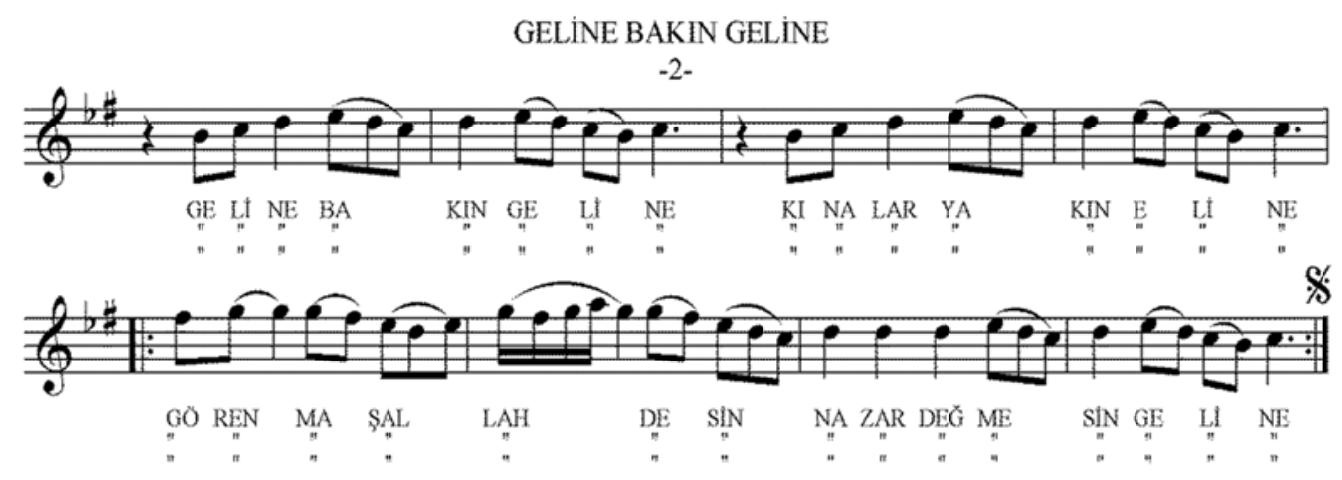

Bağlantı

GELINNE BAKIN GELINE

KINALAR YAKMIŞ ELINE

GÖREN MASALLAH DESIN

NAZAR DEĞMESIN GELINE

$-1-$

TUZ KABINI TUZSUZ KOYAN

ANASINI KIZSIZ KOYAN

KOCA EVI IZSIZ KOYAN

KIZIM KINAN KUTLU OLSUN

\section{Bağlantı}

$-2-$

BINER ATIN IYISISINE

GIDER YOLUN KIYISINA

SELÂM EDIN DAYISINA

KIZIM KINAN KUTLU OLSUN

Bağlantı

$-3-$

KIZ ANASI KIZ ANASI

HANI BUNUN ÖZ ANASI

BAK KIZIN GELIN OLUYOR

GEL AĞLA KIZIN ANASI

Bağlantı 


\section{TÜRKÜNÜN KİMLİK BILLGILERİ}

$\begin{array}{ll}\text { Adı } & : \text { Geline Bakın Geline } \\ \text { Repertuar No } & : 4600 \\ \text { Yöresi } & \text { : Amasya } \\ \text { Kimden Alındığı } & \text { : Naciye PERİN } \\ \text { Derleyen } & \text { : Ankara Devlet Konservatuarı }\end{array}$

\section{TÜRKÜNÜN USÛL ANALIZIi}

TRT THM sözlü eserler repertuarında 4600 no'lu repertuar olan “Geline Bakın Geline” adlı eserin usûl analizi aşağıdaki gibidir.

\section{Zaman}

Geleneksel Türk halk müziği nazariyatına göre; analizi yapılan eserin usûlü, 9 zamanlı usûller kapsamına girmektedir. Bu usûl, Geleneksel Türk sanat müziği usûlleri içerisinde Çifte Sofyan olarak adlandırılmaktadır.

\section{Birim}

Eser, 9 zamanlı usûl ve mertebe olarak 8'lik birim ile gösterilmiştir. Farklı mertebelere de sahip olan 9 zamanlı usûlün 4'lük mertebesi olup 9/4'lük olarak adlandırılmakta ve gerek GTHM gerekse GTSM türlerinde de kullanılmaktadır. Geline Bakın Geline adlı eserin usûlünün, 9/8'lik olduğu görülmektedir.

\section{Usûl Türü}

9/8'lik usûl GTHM nazariyatına göre; Birleşik usûller olarak gösterilmektedir. 2 ve 3 zamanlı usûllerin karma kullanılması ile oluşmaktadır. 3 zamanlı usûl yer değiştirebilmektedir. $2+2+2+3$ vuruş, $2+2+3+2$ vuruş, $2+3+2+2$ ve $3+2+2+2$ vuruş şekillerinde usûl vurulabilmektedir. Eser; 9/8'lik usûl, $2+2+2+3$ şeklinde kalıplar ile üretilmiştir.

\section{Usûl Kalıpları}

9/8'lik olan eserde kullanılan ritmik kalıplar içerisinde uzatma noktalı kalıplar kullanılmamıştır. Eserde kullanılan ritmik kalıplar aşağıdaki gibidir.

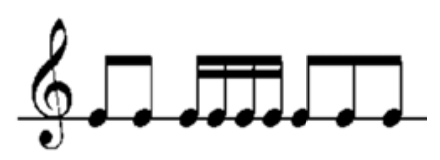

\section{Metronom}

Eserin metronomu, repertuar notası üzerinde gösterilmemiştir.

\section{Nota Süreleri}

Eser içerisinde, süreleri bakımından en uzun nota 1 vuruş değerindeki dörtlük nota, en kısa nota süresi ise $1 / 4$ değerinde on altılık nota olduğu tespit edilmiştir. Eserde, 1/2 değerinde sekizlik nota da kullanılmıştır. 
TRT MÜZIK DAIRESİ YAYINLARI THM REPERTUAR SIRA NO: 4569

INCELEME TARIHI: 18/11/2005

DERLEYEN

IZZET ALTINMEȘE

YÖRESI

DOĞU ANADOLU

DERLEME TARIHI

KIMDEN ALINDIĞI

YÖRE EKİBI

KINAYI GETIR ANEY

NOTAYA ALAN SABRI SABUNCU

SÜREST: $D=62$

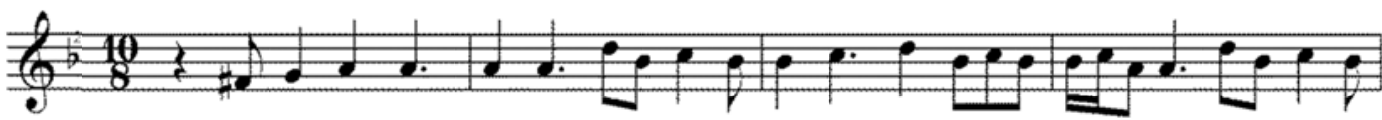

(SAZ
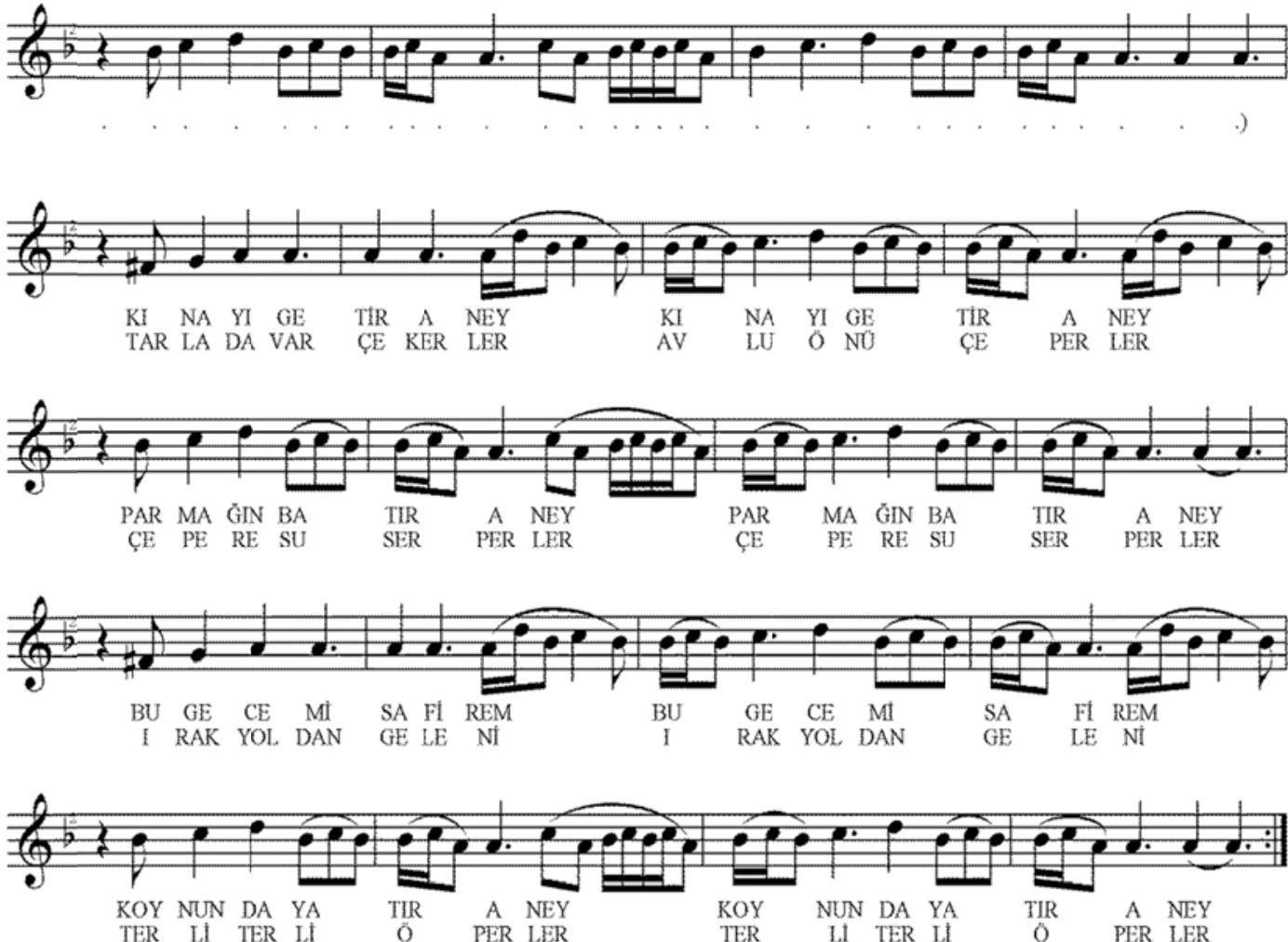

-1 -

KINAYI GETIR ANEY

PARMAĞIN BATIR ANEY

BU GECE MISAFIREM

KOYNUNDA YATIR ANEY
$-2-$

TARLADA VAR CCEPERLER CEPERE SU SERPERLER

IRAK YOLDAN GELENI

TERLI TERLI ÖPERLER
$-3-$

SIVIIK UCU KUŞ DUNI

OLDUM YARIM DÜŞKÜNI

BAS ACIK YALIN AYAK YOLA DÜŞTÜM KISৃ GÜNI

Çeper : Cit

Sivik : Evlerin çatılarında yağmur sularının akmasını sağlayan oluk.

Pun-pin : Kuş yuvası 


\section{TÜRKÜNÜN KİMLIKK BILGILLERİ}

$\begin{array}{ll}\text { Adı } & \text { : Kınayı Getir Aney } \\ \text { Repertuar No } & : 4569 \\ \text { Yöresi } & : \text { Doğu Anadolu } \\ \text { Kimden Alındığı } & : \text { Yöre Ekibi } \\ \text { Derleyen } & \text { : İzzet ALTINMEŞE }\end{array}$

\section{TÜRKÜNÜN USÛL ANALIZİ}

TRT THM sözlü eserler repertuarında 4569 no'lu repertuar olan "Kınayı Getir Aney" adlı eserin usûl analizi aşağıdaki gibidir.

\section{Zaman}

Geleneksel Türk halk müziği nazariyatına göre; analizi yapılan eserin usûlü, 10 zamanlı usûller kapsamına girmektedir. Bu usûl, Geleneksel Türk sanat müziği usûlleri içerisinde Curcuna olarak adlandırılmaktadır.

\section{Birim}

Eser, 10 zamanlı usûl ve mertebe olarak 8'lik birim ile gösterilmiştir. Farklı mertebelere de sahip olan 10 zamanlı usûlün 4'lük mertebesi olup 10/4'lük olarak adlandırılmakta ve gerek GTHM gerekse GTSM türlerinde de kullanılmaktadır. Kınayı Getir Aney adlı eserin usûlünün, 10/8'lik olduğu görülmektedir.

\section{Usûl Türü}

10/8'lik usûl GTHM nazariyatına göre; Karma usûller olarak gösterilmektedir. Karma usûller ana usûl ve birleşik usûllerin veya birleşik usûllerin karma kullanılması ile oluşmaktadır. Bir eserde en az iki usûl çeşidi olmasına çoklu usûl denilmektedir. 3 zamanlı usûl yer değiştirebilmektedir. $2+3+2+3$ vuruş, $2+3+3+2$ vuruş, $3+2+2+3$ ve $3+2+3+2$ vuruş şekillerinde usûl vurulabilmektedir. Eser; 10/8'lik usûl, $2+3+2+3$ şeklinde kalıplar ile üretilmiştir.

\section{Usûl Kalıpları}

10/8'lik olan eserde kullanılan ritmik kalıplar içerisinde uzatma noktalı kalıplar kullanılmamıştır. Eserde kullanılan ritmik kalıplar aşağıdaki gibidir.

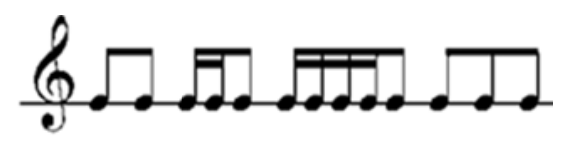

\section{Metronom}

Eserin metronomu, repertuar notası üzerinde süre değeri ile gösterilmiştir. Süre değeri olarak @ $=62$ gösterilmiştir.

Orta Yavaşlıkta edilmesi gereken bu metronomda birim süre 8'lik cinsinden gösterildiği tespit edilmiştir.

Largo - Çok yavaş (40-76 bpm) tempo ile icra edilmesi ve bu bilgiler doğrultusunda eser, largo: çok yavaş icra edilmesi gerektiği düşünülmektedir.

\section{Nota Süreleri}

Eser içerisinde, süreleri bakımından en uzun nota 1 vuruş değerindeki dörtlük nota, en kısa nota süresi ise $1 / 4$ değerinde on altılık nota olduğu tespit edilmiştir. Eserde, 1/2 değerinde sekizlik nota da kullanılmıştır. 
TRT MÜZIK DAIRESI YAYINLARI

THM REPERTUAR SIRA NO: 4244

DERLEYEN

INCELEME TARIHII: 02/02/2000

NIDA TÜFEKÇI

YÖRESI

DERLEME TARIHI

ERZINCAN-Kemaliye

KIMDEN ALINDIĞI

BURHAN TARLABAȘI

NOTAYA ALAN

SÜRESI: $:=92$

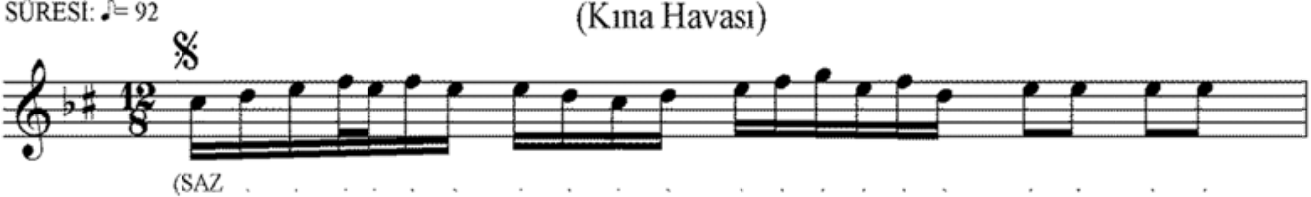

KINAYA GEL KINAYA

(Kina Havasi)
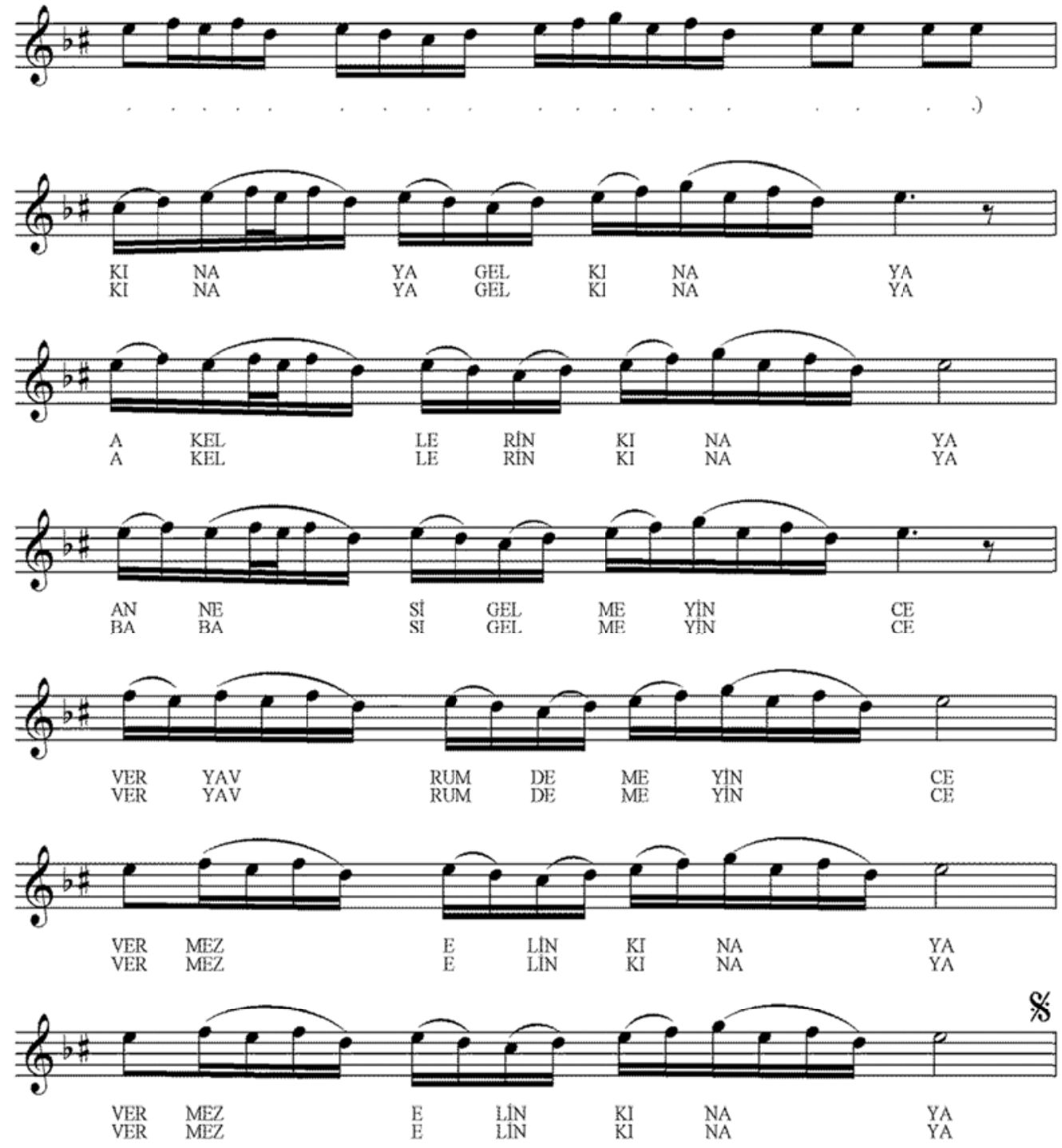
$-2-$

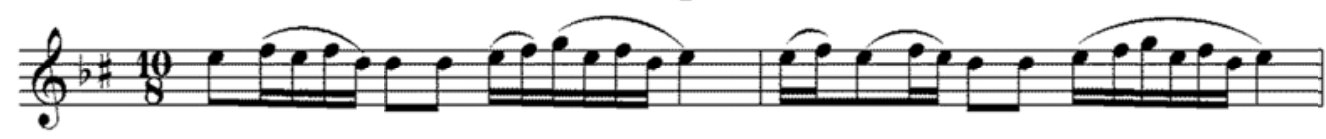

HAY Dl KI ZIM EY LI

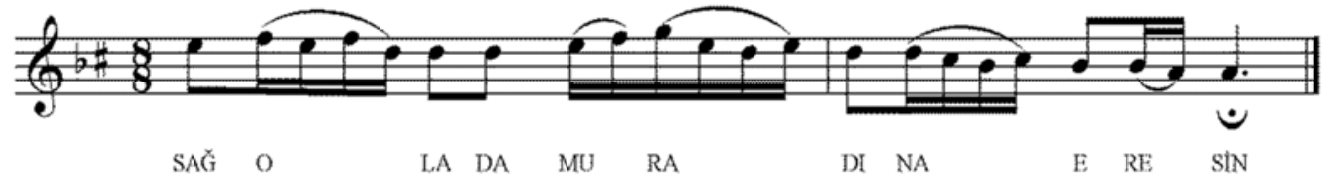

KINAYA GEL KINAYA

AK ELLERIN KINAYA

ANNESI GELMEYINCE

VER YAVRUM DEMEYINCE

VERMEZ ELIN KINAYA

VERMEZ ELIN KINAYA

KINAYA GEL KINAYA

AK ELLERIN KINAYA

BABASI GELMEYINCE

VER YAVRUM DEMEYINCE

VERMEZ ELIN KINAYA

VERMEZ ELIN KINAYA

HAYDİ KIZIM EYLIĞINEN GIDESIN

SAĞ OLA DA MURADINA ERESIN 


\title{
TÜRKÜNÜN KİMLIKK BILLGILERİ
}

\author{
Adı \\ Repertuar No \\ Yöresi \\ Kimden Alındığı \\ Derleyen
}

: Kinaya Gel Kinaya

: 4244

: Erzincan-Kemaliye

: Burhan TARLABAŞI

: Nida TÜFEKÇİ

\section{TÜRKÜNÜN USÛL ANALİZi}

TRT THM sözlü eserler repertuarında 4244 no'lu repertuar olan “Kınaya Gel Kınaya” adlı eserin usûl analizi aşağıdaki gibidir.

\section{Zaman}

Geleneksel Türk halk müziği nazariyatına göre; analizi yapılan eserin usûlü, 12,10 ve 8 zamanlı usûller kapsamına girmektedir. Bu usûl, Geleneksel Türk sanat müziği usûlleri içerisinde Bileşik Sofyan, Curcuna ve Düyek olarak adlandırılmaktadır.

\section{Birim}

Eser, 12, 10, 8 zamanlı usûl ve mertebe olarak 8'lik birim ile gösterilmiştir. Farklı mertebelere de sahip olan 10 zamanlı usûlün 4'lük mertebesi olup 10/4'lük olarak adlandırılmakta ve gerek GTHM gerekse GTSM türlerinde de kullanılmaktadır. Kınaya Gel Kınaya adlı eserin usûlünün, 12, 10, 8/8'lik olduğu görülmektedir.

\section{Usûl Türü}

12/8, 10/8 ve 8/8'lik usûl GTHM nazariyatına göre; Bileşik ve Karma usûller olarak gösterilmektedir. Birleşik usûlde 2 ve 3 zamanlı usûllerin karma kullanılması ile oluşmaktadır. Karma usûller ise Ana usûl ve birleşik usûllerin veya birleşik usûllerin karma kullanılması ile oluşmaktadır. Bir eserde en az iki usûl çeşidi olmasına çoklu usûl denilmektedir. 3 zamanlı usûl yer değiştirebilmektedir. $2+2+2+3+3$ vuruş, $2+2+3+3+2$ vuruş, $2+3+3+2+2$ vuruş, $3+2+2+2+3$ vuruş, $2+3+2+2+3$ vuruş, $2+3+2+3+2$ vuruş, $3+2+2+2+3$ vuruş, $3+3+2+2+2$ vuruş, $3+2+3+2+2$ vuruş ve $3+3+3$ vuruş şekillerinde olabileceği gibi 10/8 lik usûlde $2+3+2+3$ vuruş, $2+3+3+2$ vuruş, $3+2+3+2$ vuruş, $3+2+2+3$ vuruş ve $3+3+2+2$ vuruş ve $8 / 8$ lik usûlde de $2+3+3$ vuruş, $3+2+3$ vuruş, $3+3+2$ vuruş şekillerinde usûl vurulabilmektedir. Eser; 12, 10, 8/8'lik usûl, $3+2+3+2+2,3+2+3+2$ ve $3+2+3$ şeklinde kalıplar ile üretilmiştir.

\section{Usûl Kalıpları}

12, 10, 8/8'lik olan eserde kullanılan ritmik kalıplar içerisinde uzatma noktalı kalıplar kullanılmamıştır. Eserde kullanılan ritmik kalıplar aşağıdaki gibidir.

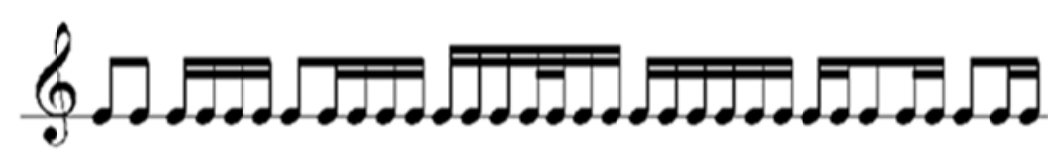

\section{Metronom}

Eserin metronomu, repertuar notası üzerinde süre değeri ile gösterilmiştir. Süre değeri olarak - $=92$ gösterilmiştir.

Orta Yavaşlıkta icra edilmesi gereken bu metronomda birim süre 8'lik cinsinden gösterildiği tespit edilmiştir. 
Andante - Orta Yavaşlikta (76-96 bpm) tempo ile icra edilmesi ve bu bilgiler doğrultusunda eser, Andante: orta yavaşlıkta icra edilmesi gerektiği düşünülmektedir.

\section{Nota Süreleri}

Eser içerisinde, süreleri bakımından en uzun nota 2 vuruş değerindeki ikilik nota, en kısa nota süresi ise $1 / 8$ değerinde otuz ikilik nota olduğu tespit edilmiştir. Eserde, 1 vuruş değerindeki dörtlük, 1/2 değerinde sekizlik ve $1 / 4$ değerinde on altılık notalar da kullanılmıştır.

\section{Sonuç ve Öneriler}

Araştırmada TRT THM repertuarında yer alan bütün türküler incelenmişs ve bu incelemeler sonucunda 75 kına türküsü olduğu tespit edilmiştir. TRT repertuarında belirlenen kına türkülerine ait genel bilgiler ortaya çıkarılıp, bu türkülere usûl analizi yapılmıştır. Kına türkülerine ait usûl oran tablosu oluşturulmuştur.

TRT THM Repertuar içerisinde bulunan toplam 75 kına türküsünün $\% 58.6$ oranıly 44 türkünün birleşik usûl, \% 17.4 oranıyla 13 türkünün ana usûl, \% 13.3 oranıyla 10 türkünün karma usûl, \% 10.7 oranıyla 8 türkünün çoklu usûl olduğu tespit edilmiştir.

Kına türkülerinin en çok birleşik usûlde olduğu, en az ise çoklu usîlde olduğu tespit edilmiştir. TRT THM repertuarındaki kına türkülerinin, \% 40 oran ile (30 türkü) 9/8'lik usûlden oluştuğu, \% 1.3 oranla ise $6 / 8,8 / 8,9 / 4,12 / 8,13 / 8,15 / 8$ 'lik usûl olduğu tespit edilmiştir. Ayrıca 8 kına türküsünün de \% 1.3 oranla çoklu usûlde olduğu tespit edilmiştir.

Ülkemizin çeşitli bölgelerinde, kına havaları gibi farklılık gösteren ağıt çeşitlerinin olduğu bilinmektedir. Diğer olaylar karşısında yakılan ağıtların da makam dizileri, usûl ve güfte yönünden incelenmesi önerilebilir.

Yapılan araştırmalar sonucunda, ağıtların genellikle edebi açıdan incelenmiş olduğu görülmektedir. Ağıtların etno-müzikoloji açısından da ele alınmasının halk kültürüne katkı sağlayacağı düşünülmektedir.

Türk Halk Müziğinde ülkemizin yörelerine özgü "Güvende, Barana havaları, Bengi gibi" kırık ve uzun hava çeşitlerinin müzikal açıdan ele alınıp değerlendirilmesinin, geleneksel kültürümüzün zenginliğini ortaya çıkarması açısından önem taşıdığı düşünülmektedir. Halk kültürü ve geleneksel müziklerimizi tanıtmak ve geliştirmek adına çeşitli eğitim faaliyetleri, seminerler, alan ile ilgili sempozyumlar yapılmasının faydalı olacağı düşünülmektedir. 


\section{REFERENCES}

- AKBAŞ, S. (2005). BEÖ-501 Spor Bilimleri Araştırma Yöntemleri, (Yayımlanmamış Sunum Raporu), Abant İzzet Baysal Üniversitesi Sosyal Bilimleri Enstitüsü, Bolu.

- AKSOY, M. (2000). Sosyal Bilimler ve Sosyoloji, Alfa Basım Yayım Dağıtım, İstanbul.

- AYDINER, M. ve ŞEN, Y. (2011). Geleneksel Türk Halk Çalgılarının Müzik Öğretmenleri Tarafindan Kullanılma Durumu, Milli Folklor, Uluslararası Kültür Araştırmaları Dergisi, Feryal Matbaacılık, Ankara.

- BÜYÜKYILDIZ, H. Z. (2009). Türk Halk Müziği-Ulusal Türk Müziği, Papatya Yayıncılık Eğitim, İstanbul.

- ClARKE, G. L. (2001). Müzik, Kimlik ve Çoğulculuk: Kanada’ya Bir Bakış, Müzikoloji Derneği Sempozyum Bildirileri, (27-28 Kasım 1999/ 20-21 Ekim 2000), Yayına Hazırlayanlar: Feza Tansuğ, Ersin Antep, Vural Yıldırım, Kitap Matbaacılık, İstanbul.

- EMNALAR, A. (1998). Tüm Yönleriyle Türk Halk Müziği ve Nazariyatı, Ege Üniversitesi Basımevi, İzmir.

- KARASAR, N. (2008). Bilimsel Araştırma Yöntemi: Kavramlar- İlkeler- Teknikler, Nobel Yayıncilık, Ankara.

- SARISÖZEN, M. (1962). Türk Halk Musikisi Usûlleri, Resimli Posta Matbaası Ltd. Şirketi, Ankara.

- TRT (2000). Türk Halk Müziği Repertuarı, Türkiye Radyo ve Televizyon Kurumu Müzik Dairesi Yayınları, No: 99, Ankara.

- TURAN, R. (2002). Kültür Alanında Gelişmeler, Türkiye Cumhuriyeti Tarihi II, Kitapta 4. Bölüm, Atatürk Araştırma Merkezi Yayınları, Ankara.

- UÇAN, A. (2005). Müzik Eğitimi Temel Kavramlar-İlkeler-Yaklaşımlar ve Türkiye'deki Durum, (3. Basım), Önder Mabaacılık Ltd. Şti., Ankara.

- YILMAZ, M. (2010). Türkiye'de Kına Yakma Geleneği ve Kına Türküleri, (Yayımlanmamış Yüksek Lisans Tezi), Cumhuriyet Üniversitesi Sosyal Bilimleri Enstitüsü, Sivas. 